\title{
Analysis of the Financial Viability of a Photovoltaic System to a Consumer Unit in South Brazil
}

\author{
Análisis de la Viabilidad Financiera de un Sistema Fotovoltaico a una Unidad de \\ Consumo en el Sur de Brasil
}

\author{
Fabrício Y. K. Takigawa ${ }^{1} \quad$ Edison A. C. Aranha Neto ${ }^{1} \quad$ Rubipiara C. Fernandes ${ }^{1}$ \\ Dyego de Campos ${ }^{1} \quad$ Mauro Cardoso ${ }^{1}$
}

Recibido 21 de abril de 2017, aceptado 5 de marzo de 2018

Received: April 21, 2017 Accepted: March 5, 2018

\begin{abstract}
The photovoltaic solar energy is a renewable energy source that is growing in the Brazilian energy scenario, mainly after the approval of Normative Resolution (REN) n ${ }^{\circ} 482 / 2012$ of the Brazilian Regulatory Agency (ANEEL). This REN establishes the general conditions of micro and mini-generation access to the distribution system (distributed energy) and the energy compensation system (net metering). The evolution of photovoltaic solar technology coupled with the new perspective created by REN 482/2012, made many consumers unities to install a photovoltaic system (PVS). However, many aspects can be considered, for example, characteristic of the installation place, solar potential of the region, distribution network (DN), connection rules, as well as the financial economic analysis of installation and its maintenance. Thus, this paper presents an analysis of PVS installation in a commercial consumer unit in Florianopolis - Brazil, considering a system design to be connected to the local DN and their financial economic analyses. Different scenarios were simulated, ranging the aspects that may influence the investment return, like the self-consumption percentage, the tariff variations over the years, the tax incidences on the generated energy, as well as the variation in the PVS size. As a result, it can be seen in scenarios that the change in the tariff over the years, the form of acquisition through financing and the possibility of energy sales can be the things that most influences the return on investment. However, in Brazil, PVS financing and energy sale are not regulated to the consumer unit yet.
\end{abstract}

Keywords: Brazilian energy scenario; photovoltaic system; sizing; financial viability; consumer.

\section{RESUMEN}

La energía solar fotovoltaica es una energía renovable que está creciendo en el escenario energético brasileño, principalmente después de la aprobación de la Resolución Normativa (REN) $n^{\circ}$ 482/2012 de la Agencia Reguladora Brasileña (ANEEL). Esta REN establece las condiciones generales de acceso de micro y mini-generación al sistema de distribución (energía distribuida) y al sistema de compensación de energía (net metering). La evolución de la tecnología solar fotovoltaica junto con la nueva perspectiva creada por la REN 482/2012, ha hecho muchas unidades consumidoras instalaren un sistema fotovoltaico $(S F V)$. Sin embargo, se pueden considerar muchos aspectos como el lugar de instalación, el potencial solar de la región, la red de distribución (RD), las reglas de conexión, así como el análisis financiero económico de la instalación y su mantenimiento. Así, este trabajo presenta un análisis de la instalación

1 IFSC - Instituto Federal de Santa Catarina. Av. Mauro Ramos, 950 - Centro - CEP 88020-300. Florianópolis, Brasil. E-mail: \{takigawa, earanha, piara, dyego.campos\}@ifsc.edu.br; maurocardoso05@gmail.com 
de un SFV en una unidad de consumo comercial en Florianópolis - Brasil, considerando un sistema para ser conectado a la RD local y sus análisis económico-financieros. Se simularon diferentes escenarios, variando los aspectos que pueden influir en el rendimiento de la inversión, como el porcentaje de autoconsumo, las variaciones tarifarias a lo largo de los años, las incidencias impositivas sobre la energía generada, así como la variación en el tamaño del SFV. Como resultado, se puede ver en los escenarios que el cambio en la tarifa a través de los años, la forma de adquisición a través del financiamiento y la posibilidad de ventas de energía pueden ser las cosas que más influyen en el retorno de la inversión. Sin embargo, en Brasil, el financiamiento de SFV y la venta de energía todavía no están regulados para la unidad de consumo.

Palabras clave: Escenario Energético Brasileño; Sistema fotovoltaico; Dimensionamiento; Viabilidad financiera; Consumidor.

\section{INTRODUCTION}

Nowadays, countries around the world seek ways to increase the supply of electric energy and to reduce emissions of greenhouse gases. For this, heads of state recognized the need to increase the percentage of renewable energy sources (RES) in the energy matrix of their countries. In this context, in order to encourage the use of RES, many countries have government incentives [1]-[2] such as specific taxes, subsidies tax or tariffs award (feed-in tariffs) [3], which are tariffs set by the government that the distribution utilities pay per $\mathrm{kWh}$ generated by a renewable source. For example, in Germany, the incentive that stands out is the application of premium tariffs, which makes the energy generated by renewable sources more attractive and competitive. An overview of the evolution of the German market and feed-in tariff policy is shown in [4]. In [3] is illustrated other applications that use the feed-in tariffs as a policy instrument for promoting RES in developing countries.

In the Brazilian energy scenario, despite government incentives still occur in an incipient way, the inclusion of renewable sources is growing, especially after the approval of Normative Resolution (REN) 482/2012 [5]. This REN establishes the general conditions to access of micro and minigeneration to the distribution system (distributed energy) and the energy compensation system (net metering), providing an increase in the installation of photovoltaic systems connected to the power distribution grid (SFCR).

The energy compensation system is based on energy credits. When the monthly generation is higher than consumption, energy credits that are valid for 60 months can be used to reduce the bill of following months of consumer units of the same owner, whereas located in the service area of the same distributor (remote self-consumption) [6].

RES are associated with the concept of distributed generation (DG), which aims to decentralize energy production, producing energy close to the place of consumption allowing ease of transmission lines and distribution systems. In Brazil, DG is decentralized energy typically use renewable energy sources (small hydro, biomass, biogas, solar and wind power) with a maximum generation capacity of up to $30 \mathrm{MW}$. Figure 1 illustrates the increase in DG connections in Brazil [7], after the approval of REN 482/2012.

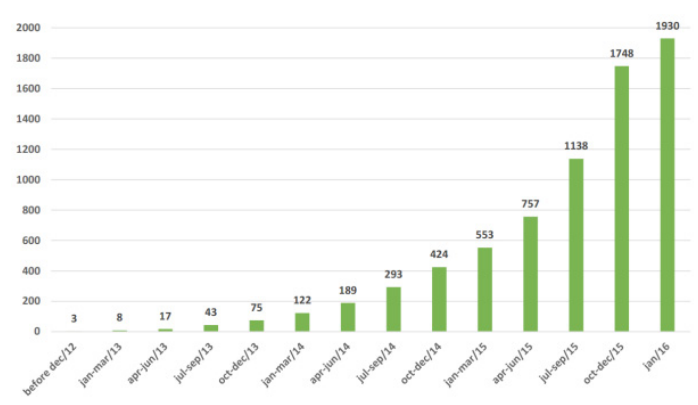

Figure 1. Number of connections until January 2016 [7].

Currently, there are more than 2,000 DG connections in Brazil, representing an installed capacity greater than 13.1 MW (In 2015, Brazil's installed capacity reached $140,858 \mathrm{MW}$, and $5.2 \%$ of this total are by wind and solar plants). Figure 2 illustrates the different installed sources of DG in 2015 [8]. It can be seen that the most used source is the photovoltaic 
system (PVS) with 1,074 connections followed by wind systems with 30 connections. The Energy Research Company (EPE), which aims to provide studies to support the Brazilian energy planning, estimates that installed capacity of photovoltaic DG will be approximately $78 \mathrm{GWp}$ in 2050 [9]. Thus, this paper aims to illustrate a design study and financial analysis of SFCR by a consumer of the Florianopolis region. Other similar works that address the Brazilian Energy Market regulation and the connection of micro and minigeneration to the distribution network can be observed in [10]-[18].

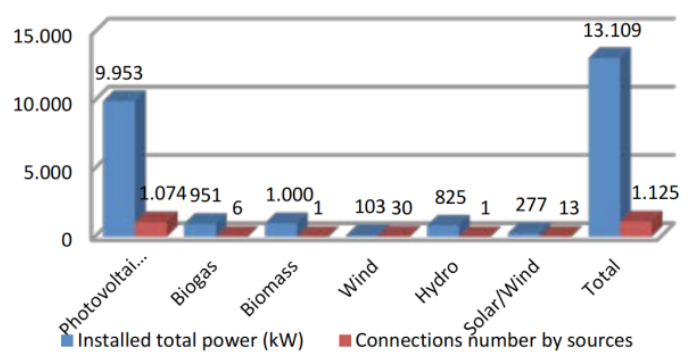

Figure 2. Brazilian DG in 2015. Adapted from [8].

\section{CURRENT REGULATION IN BRAZIL}

In November 2015, REN 482/2012 was updated by REN 687/2015 [6], which amends and extends the benefits to those who produce or wish to generate their energy. In Brazil, there is the availability cost (minimum amount charged in the energy bill), which for group B consumers is equal to $30 \mathrm{kWh}$, $50 \mathrm{kWh}$ and $100 \mathrm{kWh}$, respectively, for single-phase, bi-phase and three-phase connection and for group A consumers is the contracted demand [19].

Furthermore, there is a tax issue associated with the energy compensation system. The National Council for Financial Policy (CONFAZ) defined in the ICMS Agreement $n^{\circ} 6$ of 2013 [20], the basis calculation for the ICMS (state tax) is "the full amount of the transaction, before any compensation corresponding the total amount of energy delivered to the receiver".

To illustrate the remuneration loss due to taxation, one can compare two situations: when the generated energy is consumed in the consumer unit at the time of generation (100\% selfconsumption) and when the generated energy is injected into the distribution grid, generating energy credits for later compensation (self-consumption of less than 100\%). In the first situation, the remuneration of the generated energy will be equivalent to a reduction of the invoice amount, i.e., the energy amount value that has ceased to be consumed on the network (energy cost more tax rate). The second situation, the remuneration of generated energy will be equivalent to the energy credit to be discounted in the bill of the subsequent months; however, when the credit is posted to the bill, there is an incidence of ICMS tax on this value. Then the discount will be $25 \%$ (ICMS tax) smaller than the first situation.

In 2015, CONFAZ published ICMS Agreement $\mathrm{n}^{\circ} 16$ [21] authorizing the states to exempt ICMS charging on the energy injected into the distribution grid as a way to encourage and make more attractive the investment in generation systems. However, only a few states have joined the ICMS exemption.

\section{METHODOLOGY}

The analysis of the technical viability can be made from the information collection of installation place and the consumer unit features, which allows a dimensioning close to reality [22]. Figure 3 illustrates the flowchart of the main steps, which allow making the sizing of SFCR.

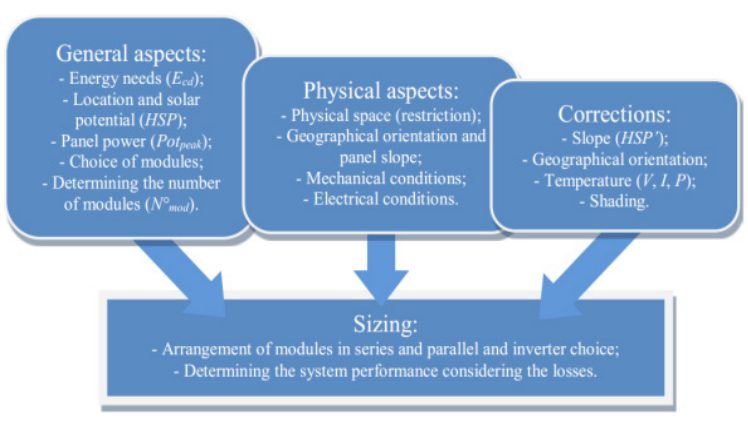

Figure 3. Stages of technical viability.

General aspects for the SFCR sizing are directly related to the ability of the system generation (energy needs of the consumer unit, geographic location, power and amount of PVS modules, and so on.). The energy needed $\left(F_{m m}\right)$ can be extracted of the energy bill or the estimated average consumption, based on the loads to be installed and use of projection. The energy in kWh to be compensated daily $\left(E_{c d}\right)$ is given by (1), when the $F_{m m}$ is subtracted from the rate of availability $\left(F_{\min }\right)$. 


$$
E c d=(F m m-F m i n) / 30
$$

Geographical location is a determining factor in the performance of the PVS, because it determines the solar irradiation on the panels. The energy potential of the region (irradiation and the average annual peak sun-HSP) can be obtained in [23]. For determination of the peak power of the panel $\left(\right.$ Pot $\left._{\text {peak }}\right)$, is used (2). This estimation brings the peak power to supply the energy needs of the consumer unit and can have an estimate of the power inverter.

$$
\text { Pot }_{\text {peak }}=E_{c d} / H S P
$$

The choice of the PVS modules must be taken into account beyond the availability of suppliers and the purchase price, the electrical parameters of operation, such as current, voltage and power, enabling a good performance in the operating conditions to which the SFCR will be subjected. The number of modules required to compose the panel, will depend directly on electrical parameters, like peak power (which impacts the total amount of modules and inverter type); voltage (which influences the maximum number of modules in series to the inverter will support); and power (which influences the maximum number of rows (strings) in parallel).

For the initial sizing of the system to be installed, the maximum power of each module (Wpmod) is known through of information given by the manufacturer. Thus, the amount of PVS modules $\left(N_{\text {mod }}^{o}\right)$, can be calculated by (3).

$$
N_{\text {mod }}^{o}=P_{\text {ot }} t_{\text {peak }} / W p_{\text {mod }}
$$

The definition of the connection point with the distribution grid is standardized and defined by the utility. The steps for enabling access are as follows: access request, the technical advice of access, connection establishment, and approval of the connection point [24]. Figure 4 shows the diagram provided by [24], bearing devices required for DN connection.

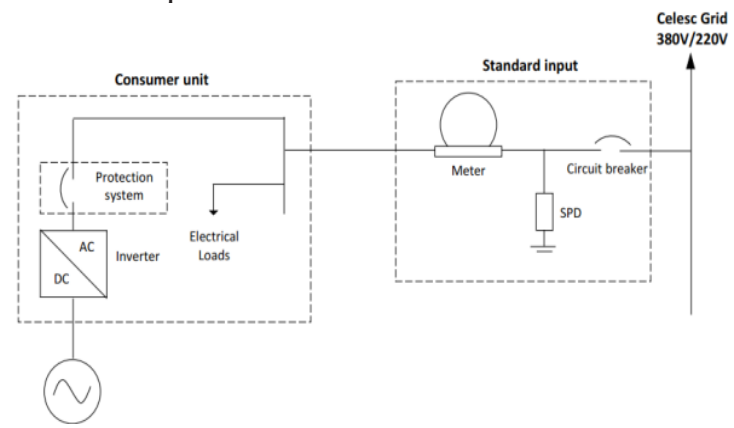

Figure 4. DN connection of micro and mini-generation.
For the installation project of a SFCR, it is essential the analysis and inspection of the physical aspects for the installation place. Nowadays, the equipment technology such as a smartphone, replace inclinometer, compass, camera, and others.

Normally, the PVS installation occurs on the roof of the consumer unit. Therefore, this may be a limitation of PVS capacity by restricting the quantity of PVS modules due to its available area, with local shading and also to solar orientation. Another significant aspect in determining the area to be occupied by the PVS is the area needed for getting around the panel during maintenance.

To determine the generation capacity and performance of the SFCR, some aspects of the installation place to be observed are the solar resource in the region, geographical orientation, the slope on which the panel will be installed, changes in local temperature and shading.

The slope of the panels is a determining factor in its ability to power generation. In most cases, the slope of the panels is determined by the existing support structure at the installation place, such as the roofs. Nevertheless, the slope may be changed according to the selected mounting structure.

In [23], it is possible to obtain the values of solar irradiation on the inclined plane and identify the slope, which has the highest average irradiation throughout the year, which for calculation purpose, may be taken as corrected HSP (HSP'). Geographical orientation is also a determining factor in the generation capacity of the PVS panel. For the southern hemisphere, the acceptable azimuth deviations are between 0 and $30^{\circ}$ from the geographic north, being deviations above $45^{\circ}$ considered critical (reduced time of exposure to the sun).

The PVS modules performance decreases with the increase of operating temperature, varying the current and voltage, which causes a variation of the maximum power that the module can generate. PVS modules bring in their specification sheets, mechanical and electrical characteristics tested in the laboratory.

To calculate the correction for temperature, first the real operating temperature of the PVS modules 
must be calculated, adding the ambient temperature $\left(T_{a m b}\right)$, which is given by the maximum temperature of the locality, obtained in [25], and $\Delta T$, which is the increase of the temperature by the fixation type [26], that depends on the ventilation that each structure allows. The only electrical quantity that will have as $T_{a m b}$ the average maximum temperature is the power, because the PVS module will not be subject to the maximum temperature at full-time. The other quantities (current and voltage) should be corrected by the maximum temperature, as it is the most critical situation that the PVS module is subject.

After obtaining the real operating temperature $\left(T_{a m b}\right.$ $+\Delta T)$, it should be subtracted from the reference temperature $\left(T_{r e f}\right)$, given in the specification sheets of the manufacturer, for the temperature calculation $\left(T_{\text {calc }}\right)$ as seen in (4).

$$
T_{\text {calc }}=\left(T_{a m b}+\Delta T\right)-T_{r e f}
$$

Defined the temperature difference to which the PVS modules will be subject after installation, the calculations of temperature for correction of the electrical of the PVS modules, such as voltage (V), current (I) and power (W) must be started.

The loss temperature, which will be applied for each quantity is calculated by $(5) . L^{\circ} \mathrm{C}$ is the calculated percentage of loss, and may take positive and negative values and $C_{o e f}$ is the temperature coefficient of the electrical quantity to be corrected, provided the manufacturer's specification sheets.

$$
L_{{ }^{\circ} \mathrm{C}}=C_{\text {oef }} * T_{\text {calc }}
$$

The performance by temperature quantity is obtained adding $100 \%$ to $L_{\circ} \mathrm{C}$. The corrected electrical quantity $\left(X_{c}\right)$ is obtained multiplying it by the value of the electrical quantity under laboratory conditions $\left(X_{s t c}\right)$, as illustrated in (6).

$$
X c=\left(100 \%+L_{{ }^{\circ} C}\right) * X_{s t}
$$

The shading analysis is a fundamental factor in determining the viability and place selection of the PVS panel installation. For this analysis, there are some tools available, such as [27], which allow a projection of the sun's trajectory throughout the day and according to the seasons (analyzing the shading of any existing elevated structure around the installation location).

To determine the PVS panel configuration, regarding their electrical connection, it must follow in addition to the shading analysis, some criteria to the choice of one or more inverters following its operational characteristics and the availability of equipment on the market. To determine the inverter output power $\left(P_{a c}\right)$, it should be considered the corrected solar irradiation (HSP') and energy compensated daily $\left(E_{c d}\right)$, as shown in (7).

$$
P_{a c}=E_{c d} / H S P^{\prime}
$$

Thus, it can be found an inverter with operation capacity close to $P_{a c}$. In manufacturer's specification sheet, the performance of the equipment $\left(\eta_{\text {euro }}\right)$ is obtained, which allows calculating the inverter power input $\left(P_{p v}\right)$, i.e., the maximum power of the panel, according to (8).

$$
P_{p v}=P_{a c} \text { 亿 }
$$

To determine the total number of modules that the drive will support $\left(M_{\text {total }}\right)$, the maximum $\left(N_{\max }\right)$ and minimum $\left(N_{\min }\right)$ number of modules in each row and the maximum number of rows in parallel $\left(N^{\circ}{ }_{\text {rows }}\right)$, are used respectively, (9).

$$
\begin{gathered}
M_{\text {total }}=P_{p v} /\left(W p^{\prime}\right) ; N_{\text {máx }}= \\
V_{d c \text { inv }} N_{o c} ; \\
N_{\text {min }}=V_{\text {min inv }} N_{m p p^{\prime}} ; \\
N_{\text {rows }}^{\circ}=\bar{I}_{\text {máx }} / I_{s c}
\end{gathered}
$$

Where:

$$
\begin{aligned}
& W p^{\prime}, V_{o c} \text {, } \quad \text { peak power of the corrected module, tension of the } \\
& V_{m p p}{ }^{\prime}, I_{s c} \text { ' fixed modules, voltage at maximum power of the } \\
& \text { fixed modules, short-circuit current corrected (6); } \\
& V_{d c_{i} i n v}, \quad \text { maximum voltage of inverter operation, } \\
& V_{\text {min_inv }}, \quad \text { minimum voltage of inverter operation, } \\
& I_{\max } \quad \text { maximum current at the inverter input. }
\end{aligned}
$$

With these calculations, the optimal configuration of series and parallel panel can be obtained, which will be consistent with current and voltage inverter operating parameters.

To determine the losses observed that the system operating conditions such as temperature, reverse efficiency, shading, dirt, mismatching, DC and AC losses and tracking losses [28]. The total loss factor or Performance Ratio $(P R)$ is determined by 
subtracting from $100 \%$ the sum of loss $K$ obtained in (10).

$$
P R=100 \%-K
$$

$P R$ may be determined for every month because there is a temperature variation during the year and therefore the loss percentage for the peak power $\left(L^{\circ} \mathrm{C}(\mathrm{Wp})\right.$ is calculated in (5), with the maximum temperature of each month.

After determining the PR, according to the physical and operational characteristics of the system, the generation of the panel, month by month, $E_{\text {real }}$ in $\mathrm{kWh}$, can be estimated, as (11).

$$
E_{\text {real }}=W_{p} * P R * H S P
$$

Beyond determining the $P R$, it should takes into account the loss of system efficiency over the years. This work considers a reduction in productivity of $0.5 \%$ per year like as [29].

\section{RESULTS AND ANALYSIS}

The consumer unit used in this case study is a commercial unit (Subgroup B3), served by CELESC utility, and connected to the three-phase distribution system for low voltage.

For being connected in a three-phase system, the cost of availability of the consumer unit is 100 $\mathrm{kWh}$ [10]. From the energy bill, it was obtained $F_{m m}=7,952.78 \mathrm{kWh}$. Also, with (1), $E_{c d}=261.76$ $\mathrm{kWh}$ was obtained.

The geographical location of the consumer unit has latitude 27.428279 (South) and longitude 48.470273 (West), carrying the average peak sun hours is $H S P=4.24 \mathrm{kWh} / \mathrm{m}^{2} /$ day [23]. With the analysis of the physical aspects of the installation place, it was found that the roof area available for fixing the photovoltaic panel facing north is 126.33 $\mathrm{m}^{2}$, with a $21.8^{\circ}$ slope.

The peak power obtained from the PVS panel (2) results in Pot $_{\text {peak }}=61.74 \mathrm{kWp}$. After the definition of the peak power of the panel, it was selected the PVS module 250 BYD P6C-30 [30]; and with (3), it was obtained the estimated PVS modules $N_{\text {mod }}^{o}=246.94$, however, as the area of each module is $1.62 \mathrm{~m}^{2}$, it was found that the maximum number of modules that can be installed is only 60. Therefore, (3) and (2) were used again for determining the panel generation and power offset daily, resulting in Pot $_{\text {peak }}=15$ $\mathrm{kWp}$ and $E_{c d}=63.6 \mathrm{kWh}$.

For the calculations of temperature correction, it was used the information from [25], where the annual average maximum temperature for the city of Florianopolis is $T_{a m b}=28.4^{\circ} \mathrm{C}$ (used to correct $\mathrm{Wp}$ ) and the maximum temperature is $T_{a m b}$ $=38.8^{\circ} \mathrm{C}$ (used for correction of the currents, $I_{m p p}$ and $I_{s c}$, and voltages $V_{o c}$ and $V_{m p}$ ). In this study, it was considered the kind of fixation on the roof with proper ventilation, which generates a $\Delta T=$ $29^{\circ} \mathrm{C}$ [26]. Thus, it was calculated the percentage losses and performance values for determining the corrected electrical quantities, based on the reference temperature and loss factors provided by the manufacturer. Table 1 shows the temperature coefficient and electric characteristics of the module chosen for this study.

Table 1. Temperature coefficients and data from laboratory [30].

\begin{tabular}{|l|l|}
\hline Coefficient $\left(\boldsymbol{C}_{\text {oef }}\right)$ & Variation \\
\hline Nominal Operating Cell Temperature & $45^{\circ} \mathrm{C} \pm 2{ }^{\circ} \mathrm{C}$ \\
\hline $\begin{array}{l}\text { Short-Circuit Current Temperature } \\
\text { Coefficient }\end{array}$ & $0,045 \% /{ }^{\circ} \mathrm{C}$ \\
\hline $\begin{array}{l}\text { Open-Circuit Voltage Temperature } \\
\text { Coefficient }\end{array}$ & $-0,34 \% /{ }^{\circ} \mathrm{C}$ \\
\hline Peak Power Temperature Coefficient & $-0,47 \% /{ }^{\circ} \mathrm{C}$ \\
\hline Power tolerance & 0 a $3 \%$ \\
\hline Quantity $\left(\boldsymbol{X}_{\text {stc }}\right)$ & Value \\
\hline Open Circuit Voltage $\left(V_{o c}\right)$ & $38 \mathrm{~V}$ \\
\hline Maximum Operating Voltage $\left(V_{m p}\right)$ & $30.4 \mathrm{~V}$ \\
\hline Short Circuit Current $\left(I_{s c}\right)$ & $8.98 \mathrm{~A}$ \\
\hline Maximum Operating Current $\left(I_{m p}\right)$ & $8.22 \mathrm{~A}$ \\
\hline Maximum Power $\left(P_{m a x}\right)$ & $250 \mathrm{Wp}$ \\
\hline Efficiency & $15.37 \%$ \\
\hline Operating Temperature & $-40{ }^{\circ} \mathrm{C} \mathrm{a} 85^{\circ} \mathrm{C}$ \\
\hline Maximum System Voltage & $1,000 \mathrm{VDC}(\mathrm{IEC}) /$ \\
\hline Irradiance in STC & $600 \mathrm{VDC}(\mathrm{UL})$ \\
\hline Temperature in STC & $1,000 \mathrm{~W} / \mathrm{m}^{2}$ \\
\hline & $25^{\circ} \mathrm{C}$ \\
\hline
\end{tabular}

Thus, with the temperature values and equations (5) and (6), the corrected values were obtained, as shown in Table 2. 
Table 2. Corrected values.

\begin{tabular}{|l|l|l|}
\hline Quantity & $\begin{array}{l}\text { Nominal Value } \\
\left(\boldsymbol{X}_{s t c}\right)\end{array}$ & $\begin{array}{l}\text { Corrected values } \\
\left(\boldsymbol{X}_{c}\right)\end{array}$ \\
\hline Peak Power $\left(W_{p}\right)$ & $250 \mathrm{~W}$ & $W_{p}{ }^{\prime}=211.93 \mathrm{~W}$ \\
\hline $\begin{array}{l}\text { Maximum Operating Voltage } \\
\left(V_{m p p}\right)\end{array}$ & $30.4 \mathrm{~V}$ & $V_{m p p}{ }^{\prime}=25.98 \mathrm{~V}$ \\
\hline Open Circuit Voltage $\left(V_{o c}\right)$ & $38 \mathrm{~V}$ & $V_{o c}{ }^{\prime}=32.47 \mathrm{~V}$ \\
\hline $\begin{array}{l}\text { Maximum Operating Current } \\
\left(I_{m p p}\right)\end{array}$ & $8.22 \mathrm{~A}$ & $I_{m p p}{ }^{\prime}=8.38 \mathrm{~A}$ \\
\hline Short Circuit Current $\left(I_{s c}\right)$ & $8.98 \mathrm{~A}$ & $I_{s c}{ }^{\prime}=9.15 \mathrm{~A}$ \\
\hline
\end{tabular}

The ideal slope to the city of Florianopolis is $23^{\circ}$ [23], close to the roof of $21.8^{\circ}$. So, it was adopted the correction of solar radiation $H S P^{\prime}=4.49 \mathrm{kWh} / \mathrm{m}^{2}$.day.

For the choice of the inverter, several criteria were observed as peak power panel, maximum and minimum voltage operation, maximum number of rows (strings) in parallel, maximum and minimum current, among others. The inverter from SMA manufacturer [26] was chosen, whose characteristics are shown in Table 3.
With (7), the output power of the inverter, $P_{a c}=14.20$ $\mathrm{kW}$, was determined. Verifying the performance of the equipment in the manufacturer's specification sheets and with (8) it was obtained $P_{p v}=14.46 \mathrm{kWp}$. To determine the total number of modules that the inverter will support, it was used (9) and it was obtained 68.21 modules. As physical space is limited, it was considered for the calculations only 60 modules. In calculating the minimum and a maximum number of modules per row, as well as the maximum number of rows it was used (9) obtaining, respectively, 24.64 and 11.55 modules, and 3.61 rows. Table 4 presents a summary of the electric panel configuration.

The determination of the losses for the performance calculation was based on data collected from the installation place [28]. The real power generated by the panel considering the $P R$ was calculated using (11) and the values obtained are shown in Table 5, where it can be observed the variation due to temperature changes.

Table 3. Inverter operating data. Adapted from [26].

\begin{tabular}{|l|l|}
\hline Type & Value \\
\hline Input (DC) & \\
\hline Max. power & $15,300 \mathrm{~W}$ \\
\hline Max. voltage & $1,000 \mathrm{~V}$ \\
\hline Rated MPPT voltage range & $300 \mathrm{~V}$ a $800 \mathrm{~V}$ \\
\hline MPPT operating voltage range & $150 \mathrm{~V}$ a $1,000 \mathrm{~V}$ \\
\hline Min. DC voltage / start voltage & $150 \mathrm{~V} / 188 \mathrm{~V}$ \\
\hline Number of MPP tracker inputs & 2 \\
\hline Max. input current/per MPP tracker input & $66 \mathrm{~A} / 33 \mathrm{~A}$ \\
\hline Output (AC) & \\
\hline Nominal power & $15,000 \mathrm{~W}$ \\
\hline Max. apparent power & $15,000 \mathrm{VA}$ \\
\hline Output phases / line connections & $3 / 3 \mathrm{~N}-\mathrm{PE}$ \\
\hline Output phases / line connections & $480 / 277 \mathrm{~V} \mathrm{WYE}$ \\
\hline Voltage range & $244 \mathrm{~V}$ a $305 \mathrm{~V}$ \\
\hline Rated grid frequency & $60 \mathrm{~Hz}$ \\
\hline Grid frequency / range & $50 \mathrm{~Hz}, 60 \mathrm{~Hz} /$ \\
\hline Max. output current & $-6 \mathrm{~Hz}$ a $+5 \mathrm{~Hz}$ \\
\hline Power factor & $18 \mathrm{~A}$ \\
\hline Harmonics & 1 \\
\hline Efficiency & $<3 \%$ \\
\hline Max. efficiency & $98.20 \%$ \\
\hline CEC efficiency & $97.50 \%$ \\
\hline
\end{tabular}


Table 4. Calculation of interactive inverter input parameters.

\begin{tabular}{|c|c|c|c|c|c|}
\hline Item & & Data & Variable & Value & Unit \\
\hline \multirow{5}{*}{ 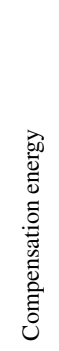 } & 1 & $\begin{array}{l}\text { Electricity consumption } \\
\text { in average monthly }\end{array}$ & $F_{m m}$ & 7952.78 & $\begin{array}{l}\mathrm{kWh} / \\
\text { month }\end{array}$ \\
\hline & 2 & $\begin{array}{l}\text { Cost monthly } \\
\text { availability }\end{array}$ & $F_{\min }$ & 100.00 & $\begin{array}{l}\mathrm{kWh} / \\
\text { month }\end{array}$ \\
\hline & 3 & $\begin{array}{l}\text { Monthly compensation } \\
\text { energy }\end{array}$ & $E_{C}$ & 7852.78 & $\begin{array}{l}\mathrm{kWh} / \\
\text { month }\end{array}$ \\
\hline & 4 & $\begin{array}{l}\text { Daily average } \\
\text { compensation energy }\end{array}$ & $E_{C D}$ & 63.60 & $\begin{array}{l}\mathrm{kWh} / \\
\text { day }\end{array}$ \\
\hline & 5 & $\begin{array}{l}\text { Daily solar radiation } \\
\text { averaged over the year }\end{array}$ & $H S P$ & 4.48 & $\begin{array}{l}\mathrm{kWh} / \\
\mathrm{m}^{2} \text {.day }\end{array}$ \\
\hline \multirow{7}{*}{ 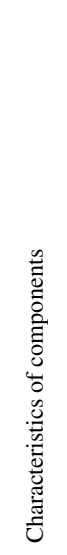 } & 6 & Inverter output power & $P_{A C}$ & 14.20 & $\mathrm{~kW}$ \\
\hline & 7 & $\begin{array}{l}\text { Average efficiency of } \\
\text { the inverter (European } \\
\text { performance) }\end{array}$ & $\bigotimes_{E U R O}$ & 0.98 & $\%$ \\
\hline & 8 & $\begin{array}{l}\text { Input power to the } \\
\text { inverter }\end{array}$ & $P P V$ & 14.46 & $\mathrm{kWp}$ \\
\hline & 9 & $\begin{array}{l}\text { Peak power of the PV } \\
\text { module (corrected) }\end{array}$ & $W p^{\prime}$ & 211.93 & $\mathrm{~W}$ \\
\hline & 10 & $\begin{array}{l}\text { Open circuit voltage of } \\
\text { the PV module (STC) }\end{array}$ & $V_{o c}$ & 32.47 & $\mathrm{~V}$ \\
\hline & 11 & $\begin{array}{l}\text { Voltage at maximum } \\
\text { power of the PV } \\
\text { module (corrected) }\end{array}$ & $V_{m p p}$ & 25.98 & $\mathrm{~V}$ \\
\hline & 12 & $\begin{array}{l}\text { Short circuit current } \\
\text { of the PV module } \\
\text { (corrected) }\end{array}$ & $I_{s c^{\prime}}$ & 9.15 & A \\
\hline \multirow{7}{*}{ 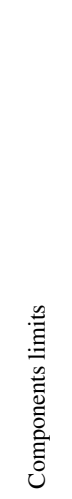 } & 13 & $\begin{array}{l}\text { modules amount in } \\
\text { panel }\end{array}$ & $M_{\text {total }}$ & 68.21 & UN \\
\hline & 14 & $\begin{array}{l}\text { Maximum voltage inverter } \\
\text { input }\end{array}$ & $U_{D C, i n v}$ & 800 & $\mathrm{~V}$ \\
\hline & 15 & $\begin{array}{l}\text { Minimum voltage } \\
\text { inverter input }\end{array}$ & $U_{m i n M P P, i n v}$ & 300 & $\mathrm{~V}$ \\
\hline & 16 & $\begin{array}{l}\text { Maximum current inverter } \\
\text { input }\end{array}$ & $I_{\max , i n v}$ & 33 & A \\
\hline & 17 & $\begin{array}{l}\text { Maximum number of } \\
\text { modules in the inverter }\end{array}$ & $N_{\max }$ & 24.64 & UN \\
\hline & 18 & $\begin{array}{l}\text { Minimum number of } \\
\text { modules in the inverter }\end{array}$ & $N_{\min }$ & 11.55 & UN \\
\hline & 19 & $\begin{array}{l}\text { Maximum rows (strings) } \\
\text { in parallel }\end{array}$ & $N_{\text {strings }}$ & 3.61 & UN \\
\hline
\end{tabular}

Table 5. Effective panel generation.

\begin{tabular}{|l|l|l|l|l|l|l|l|l|l|l|l|l|}
\hline & Jan & Feb & Mar & Apr & Mai & Jun & Jul & Aug & Sep & Oct & Nov & Dec \\
\hline $\boldsymbol{k W p}$ & 15 & 15 & 15 & 15 & 15 & 15 & 15 & 15 & 15 & 15 & 15 & 15 \\
\hline $\boldsymbol{P R}$ & 0,75 & 0,75 & 0,75 & 0,76 & 0,78 & 0,78 & 0,79 & 0,79 & 0,78 & 0,78 & 0,77 & 0,76 \\
\hline $\boldsymbol{H S P}$, & 5,38 & 5,24 & 5,02 & 4,45 & 3,81 & 3,29 & 3,43 & 3,94 & 4,14 & 4,55 & 5,11 & 5,44 \\
\hline $\boldsymbol{E}_{\text {real }}(\boldsymbol{k W h / d a y )}$ & 60,69 & 58,95 & 56,80 & 51,04 & 44,31 & 38,71 & 40,49 & 46,49 & 48,67 & 52,87 & 58,78 & 61,91 \\
\hline $\boldsymbol{E}_{\text {real }}(\boldsymbol{M W h}$ /month) & 1,881 & 1,651 & 1,761 & 1,531 & 1,374 & 1,161 & 1,255 & 1,441 & 1,460 & 1,639 & 1,764 & 1,919 \\
\hline
\end{tabular}

The analysis of the return of investment was based on the projection of revenue generation over the years, considering the projection of the tariff adjustment and all expenses involved. Since this analysis was made for a SFCR in a consumer unit attended by CELESC, it was obtained the applied energy tariff value, $0.633082 \mathrm{R} \$ / \mathrm{kWh}$, with (12). 
Tariff $(\mathrm{R} \$)=$

(tariff published by ANEEL)

[1-(PIS+COFINS+ICMS)/100]

For this case study, it was considered a red tariff flag on level 2 (R\$ 4.50 per $100 \mathrm{kWh}$ ) throughout the period, then obtained a fixed rate of $0.6781 \mathrm{R} \$ /$ $\mathrm{kWh}$. For the revenue calculation over the years, it was considered a tariff inflation of $10 \%$ and performance of loss factor of $0.5 \%$ system. It was considered a cost of capital of $10 \%$, close to the IPCA of 2015 [31]. Initial costs were determined through market research [32-33] and the lowest price of purchase and installation of a $15 \mathrm{kWp}$ system was $\mathrm{R} \$ 107,205.00$. For maintenance costs, an annual payment of $0.5 \%$ of the initial investment was considered [28].

The analysis of the obtained values allows identifying an internal return rate of $18.80 \%$. To determine the discounted payback, it was elaborated a cash flow with the present corrected values, with a capital cost of $10 \%$ by subtracting from the revenue, the annual cost, as illustrated in Figure 5. The return of investment time for this case study is 10 years.

The simulation of different scenarios was performed different aspects that directly influence the financial returns as a percentage of energy injected into the network (self-consumption), tariff inflation, SFCR size, inverter exchange, system acquisition and the possibility of energy sale (if there was the regulation possibility). Table 6 shows a comparative summary of scenarios performed. It can be seen that the return of investment time can change widely (7-17 years), depending on the system that will be acquired, the annual rate of inflation and regulation on the marketing of the energy produced.

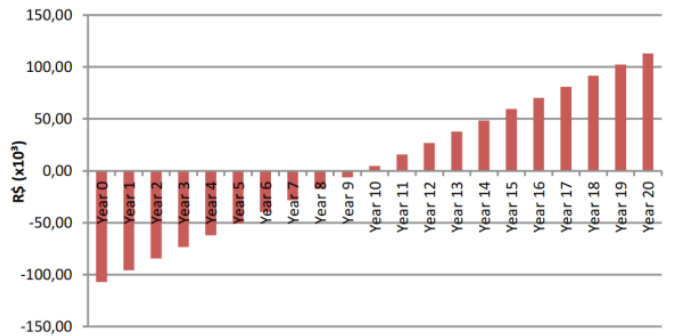

Figure 5. Chart cash flow.

In Table 6, it may also be noted that in some scenarios $(9,10,14$ and 15), the consumer has the possibility of selling (10\% above or below of the energy tariff) the surplus of its PVS generation (when the monthly generation is higher than consumption), instead of maintaining the energy credits. However, currently, in the Brazilian market, it is even not possible.

Table 6. Scenarios.

\begin{tabular}{|c|c|c|c|c|c|c|c|c|}
\hline Scen. & System $(\mathbf{k W p})$ & Acquis. (R\$) & Form & Tariff adj. (\%) & Self-Cons. (\%) & Inverter exchange & TIR(\%) & Return (yrs) \\
\hline Base & 15 & $107,250.00$ & In cash & 10 & 100 & No & 18.80 & 10 \\
\hline 1 & 15 & $95,525.00$ & In cash & 10 & 100 & no & 20.47 & 9 \\
\hline 2 & 15 & $107,250.00$ & In cash & 10 & 100 & yes & 18.53 & 11 \\
\hline 3 & 15 & $107,250.00$ & In cash & 10 & 71 & no & 17.67 & 11 \\
\hline 4 & 15 & $95,525.00$ & In cash & 10 & 71 & no & 19.26 & 10 \\
\hline 5 & 15 & $107,250.00$ & Financed & 10 & 71 & no & 29.56 & 10 \\
\hline 6 & 15 & $107,250.00$ & Financed & 10 & 100 & no & 35.33 & 8 \\
\hline 7 & 15 & $107,250.00$ & In cash & 7 & 71 & no & 14.79 & 13 \\
\hline 8 & 15 & $107,250.00$ & In cash & Last 10 years & 71 & no & 11.33 & $\mathbf{1 7}$ \\
\hline 9 & 15 & $107,250.00$ & In cash & Sale $(+10 \%)$ & 100 & no & 20.29 & 9 \\
\hline 10 & 15 & $107,250.00$ & In cash & Sale (- 10\%) & 100 & no & 17.22 & 11 \\
\hline 11 & 60 & $394,990.00$ & In cash & 10 & 71 & no & 19.18 & 10 \\
\hline 12 & 60 & $394,990.00$ & Financed & 10 & 71 & no & 38.40 & 8 \\
\hline 13 & 60 & $394,990.00$ & Financed & 10 & 100 & no & 47.80 & $\mathbf{7}$ \\
\hline 14 & 60 & $394,990.00$ & In cash & Sale $(+10 \%)$ & 100 & no & 20.69 & 9 \\
\hline 15 & 60 & $394,990.00$ & In cash & Sale (- 10\%) & 100 & no & 17.61 & 11 \\
\hline
\end{tabular}




\section{CONCLUSIONS}

This work presented the different stages for designing an SFCR. The economic and financial analysis identifies the aspects that influence the financial return to the consumer unit. With the simulation of different scenarios, it can be seen that the change in the tariff over the years can be the thing that influences the return on investment because it is directly linked to the avoided cost with the purchase of energy distribution. On the one hand, the form of acquisition through financing and the possibility of energy sales are aspects that are not regulated in Brazil, but can contribute significantly to the acquisition and system payback time. Attention should be paid to different tariffs (white tariff, for example) and external trends that may encourage government action in the political and economic aspects. As governmental incentives can change formats in taxation and compensation and energy trading system. On the other hand, the DG expansion in the Brazilian energy matrix is a close reality. Therefore, it is very important to analyze and proposed ways of energy management for the consumer side with solar generation like [34].

Furthermore, other points can be addressed in the analysis of the financial viability, such as different types and configurations of modules and inverters (currently have several brands in the market), analysis of solar radiation and generation, exemption of ICMS taxes, different tariffs, demand side management, others energy sources with PVS (like battery bank and small wind generation) and others government incentives.

\section{ACKNOWLEDGMENT}

The authors would like to thank the Brazilian National Council for Scientific and Technological Development (CNPq), the Federal Institute of Santa Catarina (IFSC) and the International Research Staff Exchange Scheme (IRSES) (Marie Curie) in the ELECON Project for the research support.

\section{REFERENCES}

[1] IRENA, International Energy Agencia. Date of visit: Out 11, 2016. URL: https://www.iea. org/policiesandmeasures/renewableenergy/.

[2] S. Cox, T. Walters, S. Esterly and S. Booth. "Solar Power. Policy Overview and Good Pratices".
2015. Date of visit: Fev 28, 2017. URL: https:// www.nrel.gov/docs/fy15osti/64178.pdf

[3] W. Rickerson. "Feed-in Tariffs as a Policy Instrument for Promoting Renewable Energies and Green Economies in Developing Countries" 2012. URL: http://www.unep. org/pdf/UNEP_FIT_Report_2012F.pdf.

[4] M. Fulton and N. Mellquist. "The German Feed-in Tariff for PV: Managing Volume Success with Price Response", 2011. Date of visit: Fev 28, 2017. URL: https://www. db.com/cr/en/docs/German_FIT_for_PV.pdf

[5] ANEEL, "Resolução Normativa n ${ }^{\circ} 482$ de 17 de Abril de 2012". Date of visit: Mar 20, 2017. URL: http://www2.aneel.gov.br/cedoc/ren2012482.pdf.

[6] ANEEL. "Resolução Normativa $n^{\circ} 687$ de 24 de Novembro de 2015". Date of visit: Mar 20, 2017. URL: http://www2.aneel.gov.br/ cedoc/ren2015687.pdf.

[7] ANEEL "Novas regras para geração distribuída entram em vigor". Date of visit: Mar 20, 2017. URL: http://www2.aneel. gov.br/aplicacoes/noticias/Output_Noticias. cfm?Identidade $=9086 \&$ id_area $=90$.

[8] ANEEL. "Geração Distribuída supera 1000 conexões no Brasil". Date of visit: Nov 25, 2016. URL: http://www2.aneel.gov. br/aplicacoes/noticias/Output_Noticias. cfm?Identidade $=8899 \&$ id_area $=90$.

[9] EPE. "Nota Técnica DEA 13/14: Demanda de Energia em 2050". Date of visit: Mar 20, 2017. URL: http://www.epe.gov.br/Estudos/ Documents/DEA\%2013-14\%20Demanda\%20 de\%20Energia\%202050.pdf.

[10] G.Zanetti Neto, W.T.Costa and V.B. Vasconcelos. “A Resolução Normativa n 482/2017 da ANEEL: Possibilidades e Entraves para a Microgeração Distribuída". V Congresso Brasileiro de Energia Solar. Recife, 2014.

[11] D.H.S.M. Maciel and A.U. Brito. "Política Pública de Investimento em Sistemas Fotovoltaicos Conectados à Rede frente ao Enquadramento Tarifário". V Congresso Brasileiro de Energia Solar. Recife, 2014.

[12] R.D. Castro. C.A. Melo. "Análise Da Difusão Da Geração Fotovoltaica Distribuída No Brasil: Previsões E Realidade". VICongresso Brasileiro de Energia Solar. Belo Horizonte, 2016.

[13] A.R.O. Rosa and F.P. Gasparin. "Panorama da Energia SolarFotovoltaica no Brasil". VICongresso Brasileiro de Energia Solar. Belo Horizonte, 2016. 
[14] F.B.M. Trigoso and C.B. Andrade. "Marco Regulatório Brasileiro da Geração Distribuída Baseada em Sistemas Fotovoltaicos". VICongresso Brasileiro de Energia Solar. Belo Horizonte, 2016.

[15] T.M.G. Costa, D.L. Sebben and S.M. Silva, "Evolução do Mercado de Geração Distribuída a Partir da Audiência Pública n ${ }^{\circ} 26$ no Ano de 2015". VI Congresso Brasileiro de Energia Solar. Belo Horizonte, 2016.

[16] S.M.S. Bezerra, P.S.R. Araújo, D. Barbosa and C.H. Duarte. "Motivações e Impactos da Geração Distribuida Fotovoltaica Conectada a Rede na Matriz Energética Brasileira". VI Congresso Brasileiro de Energia Solar. Belo Horizonte, 2016.

[17] G. Konzen, P. Krenza, P.S. Manoela and R. Rüther, “OMercado de Geração Distribuída(GD) Fotovoltaica no Brasil". VI Congresso Brasileiro de Energia Solar. Belo Horizonte, 2016.

[18] D. Tenfen, F.A.B. Lemos, R.C. Fernandes and I.C. Decker. "Microgrids and Microgeneration in Brazilian Energy Market: a Discussion of Regulatory and Commercial Aspects", 9th LatinAmerican Congress on Electricity Generation and Transmission. Viña del Mar, 2013.

[19] CELESC. "Resolução Homologatória no 1.927 de 04 de Agosto de 2015". Date of visit: Aug 10, 2016. URL: http://novoportal.celesc.com.br.

[20] CONFAZ. "Convênio ICMS 6 de 05 de Abril de 2013". Date of visit: Out 23, 2016. URL: https://www.confaz.fazenda.gov.br.

[21] CONFAZ. "Convênio ICMS 16 de 22 de Abril de 2015". Date of visit: Out 23, 2016. URL: https://www.confaz.fazenda.gov.br.

[22] J.T.Pinho andM.A. Galdino. "Manual deEngenharia para Sistemas Fotovoltaicos". CEPEL-CRESESB. Rio de Janeiro, 2014.

[23] CEPEL-CRESESB. "Potencial Solar". Date of visit: Jul 15, 2016. URL: http://www.cresesb.cepel.br.
[24] CELESC. "Normas Técnicas: Conexão de Micro ou Mini Geradores de Energia oa Sistema Elétrico da Celesc Distribuição". Date of visit: Fev 28, 2017. URL: http:// novoportal.celesc.com.br.

[25] INMET. "Normas Climatológicas". Date of visit: Jul 14, 2016. URL: http://www.inmet.gov.br.

[26] SMA. "Manual de Equipamento". Date of visit: Jul 18, 2016. URL: http://www.smabrazil.com/.

[27] Sun surveyor. "Sun and Moon Position Visualization App". Date of visit: Out 11, 2016. URL: http://www.sunsurveyor.com/.

[28] R.D. Souza. "Apostila Técnica Blue Sol para Dimensionamento de Sistemas Fotovoltaicos". Ribeirão Preto, 2014.

[29] A.A. Montenegro. "Avaliação do retorno do investimento em sistemas fotovoltaicos integrados a residências unifamiliares urbanas no Brasil". Master's thesis. UFSC. Florianópolis, 2013.

[30] BYD. "Equipment Datasheet". Date of visit: Jul 20, 2016. URL: http://www.byd.com.

[31] IBGE. "Índice Nacional de Preços ao Consumidor Amplos". Date of visit: Fev 21, 2017. URL: http://www.ibge.gov.br.

[32] Quantum solar. "Orçamento para aquisição de um Sistema fotovoltaico conectado à rede". São José, 2016.

[33] Neosolar. "Kits Energia Solar: Conexão à rede - Grid-tie". Date of visit: Fev 14, 2017. URL: http://www.neosolar.com.br.

[34] F.Y.K. Takigawa, R. C. Fernandes, E.A.C. Aranha Neto, D. Tenfen and E.T. Sica. "Energy Management by the Consumer with Photovoltaic Generation: Brazilian Market". IEEE Latin America Transactions. Vol. $14 \mathrm{~N}^{\circ}$ 5, pp. 2226-2232. 2016. DOI: 10.1109/TLA.2016.7530417. 